\title{
The Analysis of Influence of Job Stressor upon Performance and Turnover Intention \\ of Broker-Dealer of Equity Securities in Surabaya
}

\author{
Bambang Hadi Santoso Dwidjosumarno \\ Doctoral Student in Economics, Airlangga University, Surabaya, East Java-Indonesia \\ Lecturer in Sekolah Tinggi Ilmu Ekonomi Indonesia (STIESIA) Surabaya, East Java-Indonesia \\ Indonesia \\ dwidjosumarno@gmail.com
}

\begin{abstract}
The long-term goal of this research is to make the Indonesian capital market equals/parallel to other capital markets in the Asia Pacific region. The research is conducted in securities companies which are Members of Indonesia Stock Exchange located in Surabaya City, East Java Province. The number of domestic investors in the capital market in Indonesia is still very limited, reaching only about 400 thousand people, or less than $0.1 \%$ of the number of Indonesia's middle class who already have securities accounts as an active sign of becoming a financier in the stock exchange (Afifuddin, 2011). This situation is a problem that needs to get serious attention from the government to enliven the Indonesian capital market, so the dream of making the Indonesian capital market parallel to the capital markets in the Asia Pacific region can be realized. The number of domestic investors needs to be increased so that ownership of equity securities is not only dominated by foreign investors. Such condition of the Indonesian capital market is inseparable from the role and performance of Broker-Dealer of Equity Securities (PPEE), so this is a problem that needs to be studied.
\end{abstract}

The research variables consist of independent variables consisting of role ambiguity, role conflict, and role overload variables, as well as dependent variables consisting of performance variables and turnover intention. Sampling is done by purposive sampling method, while statistical data analysis is done by using Structural Equation Modeling Method.

The result of this research is the result of hypothesis testing as follows: 1). There is no significant influence between role ambiguity and PPEE performancein Surabaya, 2). There is no significant influence between role conflict and PPEE performance in Surabaya, 3). There is a significant influence between role overload and PPEE performancein Surabaya, 4). There is no significant influence between role ambiguity and PPEE turnover intention in Surabaya, 5). There is no significant influence between role conflict and PPEE turnover intention in Surabaya, 6). There is a significant influence between role overload and PPEE turnover intention in Surabaya, and 7). There is a significant negative effect between performance and PPEE turnover intention in Surabaya.

Keywords: role ambiguity, role conflict, role overload, performance, and turnover intention.

\section{INTRODUCTION}

\section{Research Background}

The number of local investors in investing effective equity securities (stocks) in Indonesia capital market is still limited in number, which is indicated by the number of ownership of shares by local investors in Indonesia are still far behind when compared with Malaysia, Singapore and Japan. PT KustodianSentralEfek Indonesia (PT KSEI) notes that the number of local investors in Indonesia only reaches $0.2 \%$ of the total population of Indonesia (up to 300,000 people, whereas the population of Indonesia has more than 200 million people). Of the 300,000 local financiers, 200,000 of them are new local financiers, meaning that the local Indonesian financiers are only reached 100,000 people. Local investors in the Malaysian capital market accounted for $15 \%$ of Malaysia's population, and in Singapore accounted for 30\% of Singapore's population.

Up to the end of 2012, based on data from PT KSEI, the value of foreign share ownership is reached $67.10 \%$ (Rp 772,572 billion) of the total value of shares of Rp. 1.151.354 billion. Until the end of 2013, based on data from the same source, the amount of foreign share ownership still dominates (reaching $62.80 \%$ or Rp 1,184,282 billion) of the total value of shares outstanding in Indonesia capital market. Thus, the local investors only control $32.90 \%$ each at the end of 2012 and $37.20 \%$ of shares by the end of 2013 . Meanwhile, the data up to June 2014 shows that foreign share ownership is still high (as much as $63,42 \%$ or $\mathrm{Rp}$ $1,313,015$ billion) of the total value of shares of $\mathrm{Rp}$. 2,070,473 billion.

In organizations, the conditions of "role stress" associated with a particular aspect of an individual's role have gained considerable attention (Johnston et al., 2000 in Babakus et al., 2006). According to Michael et al., 2004 in Babakus et al., 2006, there are two major components of stress, i.e. role ambiguity and role conflict which have a significant impact on work attitudes and behavior. Research on stress, particularly work stress which comes from individual roles in the organization, shows that role ambiguity and role conflict are related to negative work, 
including low job satisfaction and organizational commitment, decreasing job performance, high job tension, and high job change intentions (Jackson et al., 1995 in Viator, 2000). The stress condition of individual roles in the organization is also in accordance with Sullivan et al., 2000 study in Iswanto (2002): that stress is measured by role conflict, role ambiguity, and role overload has a negative relationship to performance. The Rajab et al (2013) study also concludes that role conflict, role ambiguity, and role overload have a negative relationship to performance, and even to organizational commitment.

The stress situation within an organization can be experienced by every employee, including in the capital market, such as Broker-Dealer Representatives (WPPE) which is a stockbroker, is commonly known as an Equity Broker-Dealer (PPEE). They come from securities companies, as well as members of the Indonesia Stock Exchange. They always make direct interaction with the investor community, functioning as a liaison role, in which this role is the norm for those people to experience conflict or obscurity while they carry out their work (Johnson et al., 2000 in Marck, 2007).

Facing such conditions, it is a challenge for managers of the capital market industry in charge of managing public funds and marketing various investment instruments which have been produced by the industry. It can be argued that capital market industry managers, especially those who interact directly with the capitalist community, are at the forefront of securities companies, which play a major role, especially for the growth of these securities firms, and ultimately for the financial industry "capital market" in general. Therefore any securities firm is required to increase quality and professionalism of its PPEE, considering the role of PPEE is very important, because of its influence on the acquisition value of stock transactions and the number of investors (local and foreign), as well as a market maker. When the value of stock transactions that can be achieved is getting great, it means that more and more people are investors who make transactions, as well as when the market capitalization and the composite stock price index is getting great. Outcomes/performances that include the value of stock transactions, the number of investors (local and foreign), the securities market capitalization, and the securities index are not only beneficial to the PPEE individuals, but also for securities firms where the PPEE works, In Indonesia as a whole.

Being the PPEE, which requires the PPEE to always interact with the capitalist community, is not easy.The PEEE from securities firms often face problems, in the form of a lack of clarity of information about the limitation of duties and responsibilities to the investors and to securities companies. Such conditions create uncertainty for the PPEE of a securities company in performing its role.

Every problem, work demands and pressure from the organization can disrupt the concentration of the work in terms of the implementation of its work and its adjustment to the work environment, which in itself causes stress: the form of stress in the employee. This condition is in accordance Robbins (2008), that the causes of stress in the work environment include: task demands, role demands, interpersonal demands, organizational structure and leadership in the organization, where every employee who is involved in the organization a bit more will experience pressure in work activities related to the existence of such sources of pressure. Davis and Newstrom in Margiati (1999) express the same opinion that job stress is caused by too many tasks, lack of intelligence, limited time to complete a job, lack of adequate responsibility, role ambiguity, different values with the company, Frustration, change of work type and role conflict. This is in line with the Kreitner (1992) and Minner (1998) models in Iswanto (2002), which suggest that job characteristics cause work stress that has variations and dimensions including role overload, role conflict, role ambiguity and responsible for people.Behrman et al., 1984 in Singh (1998) states that job stress originating from individual roles in the organization typically consists of role conflict, role ambiguity, and role overload. The stress resulted in disadvantage of the employee (without exception PPEE), which ultimately had a disadvantageous impact on securities firms, and ultimately can affect the whole capital market industry. High stress can interfere with job performance, so it can affect the concentration of employees in decision making and job control, behavior that becomes less controllable, and ultimately will result in a decrease in productivity and employee performance.

Profession as the PPEE is a stressful job/ pressure. A result of a research states that some securities companies are reporting out of the PPEE in the same year (Samsuri, 2011). The PPEE who cannot handle their task/strain end up leaving their organization/profession. Job stress experienced by employees also does not close the possibility of increased employee turnover intentions (Scotter, 2000). McEvoy (1987) in Scotter (2000) states that performance and turnover intention have negative correlation (indicating that employees with good performance, not quit his job, vice versa). Turnover intention will be "considered functional" if employees with poor performance out of their jobs or leave their jobs.

Departing from all these conditions, it is necessary to examine the effects of job stress/role stress (role ambiguity, role conflict and role overload) variables that the PPEE is likely to experience on their performance and turnover intention.

\section{Research Problems}

Based on thebackground of theresearch, the research problemscan be submitted as follows: 1). Does role ambiguity affect the performance of PPEE in Surabaya? 2). Does role conflict affect the performancePPEE in Surabaya? $3)$. Does role overload affect the performance of PPEE in Surabaya? 4). Does role ambiguity affect PPEE turnover intention in Surabaya? 5). Does the role conflict affect the turnover intention of PPEE in Surabaya? 6). Does role overload affect PPEE turnover intention in Surabaya?and 7). Does the performance affect the turnover intention of PPEE in Surabaya? 


\section{Research Objectives}

Research objectives: 1). Analyze and prove that role ambiguity influences the performance of PPEE in Surabaya, 2 ). Analyze and prove that role conflict influence to performance of PPEE in Surabaya, 3). Analyze and prove that role overload influences the performance of PPEE in Surabaya, 4). Analyze and prove that role ambiguity has an effect on PPEE turnover intention in Surabaya, 5). Analyze and prove that role conflict influences PPEE turnover intention in Surabaya, 6). Analyze and prove that role overload affects tournament intention of PPEE in Surabaya, and (7) Analyze and prove that performancePPEE influences PPEE turnover intention in Surabaya.

\section{LITERATURE REVIEW AND HYPOTHESIS}

\section{Previous Researches}

Previous research was conducted by Rageb et al., 2013, with research variables: organizational commitment, job satisfaction, job performance, role conflict, role ambiguity, role overload, and turnover intention. The results of his research are: 1). Role conflict, role ambiguity, and role overload are negatively correlated to performance, 2). Role conflict, role ambiguity, and role overload are positively correlated to turnover intention, 3). Performance is negatively correlated with turnover intention, and 4). Organizational commitment, job satisfaction, and job performance mediate role stressors (role conflict, role ambiguity, and role overload) and intentions to leave. Rageb et al's research was conducted on the employees of Arab Academy for Science \& Technology \& Maritime Trasnport, College of Management \& Technology, Alexandria, Egypt. Previous research has also been done by Tang and Chang (2010), with research variables role ambiguity, role conflict and employee creativity in manufacturing companies, with the following research results: 1). Role ambiguity positively correlates to employee creativity, and 2). Role conflict negatively correlates to employee creativity. In 2009, Tee conducted research on insurance agents, with research variables: role ambiguity, role conflict, role overload and performance of insurance agents, with the results of research as follows: 1). Role ambiguity positively correlated to insurance performanceagent, 2). Role conflict is negatively correlated with the performance of insurance agents, and 3). Role overload is negatively correlated with insurance agent performance.

\section{Job Stress and Cause of Job Stress}

Stress according to Robbins and Judge (2008): a dynamic condition in which an individual is exposed to the opportunities, demands, or resources associated with what the individual desires and whose results are deemed uncertain and important. The three categories that are the source of stressor potentials according to Robbins and Jugde are factors: environment, organization, and personal. Factors in the organization/work are basically grouped into five categories: (1) intrinsic factors in work: physical demands and task demands, (2) individual roles in the organization: role conflict and role ambiguity, (3) career development: Job certainty and lameness of status, (4) relationships in work, or labor relations, and (5) organizational structure and climate.

Stress role is the stress associated with certain aspects of the role of individuals within the organization. Two main components of stress: role ambiguity and role conflict. The role disfunction is a stress generator, namely: role conflict and role ambiguity (Hurrel in Munandar, 2001). Rizzi et al. in Babakus (2006) defines role ambiguity as a situation in which an individual has no clear direction about the expectations of his/her role in the work/organization, and role conflict is defined as the incompatibility of expectations communicated to perceived performance, for example at the time consumer demand and supervisors are conflicting, then the sales force is likely to experience role conflict. Puspa et al., 1999 in Iswanto (2002) states: role conflict is a psychological phenomenon experienced by members of the organization that can cause insecurity in the work, and potentially can reduce the motivation of work. The emergence of role conflict is when there is more than one request from a different source, which can lead to an uncertainty in the employee (Towner, 2010). According to Towner, the rise of role conflict is due to the fact that two different orders are received simultaneously, in which the execution of a single command will result in the neglect of another order, which will cause confusion for the employee who receives the order, especially if the order contradicts between the One with the other.

George et al., 2002 says: the role is a set of behaviors/tasks a person is expected for his position in the organization. Three sources of stress on the role of individuals in the organization: role conflict, role ambiguity, and overload-underload. Role conflict occurs when behaviors and tasks are expected to conflict with each other, role ambiguity is a powerful source of stress for new employees in an organization/workgroup, and overload occurs in a condition where employees have too many tasks to perform, as well as the underload occurs in a condition in which the employee does not have sufficient tugs to do. Such conditions are a source of stress for employees.

\section{The Correlation of Work Stress towards Performance}

According to Siagian (2010), stress greatly affects performance. Rajeb et al., 2013 reveals the results of his research: role stressors, role conflict, role ambiguity, role overload, and novelty roles have a negative relationship to performance. Tohardi (2002) states if there is no stress at all, it cannot be said well, because there is no challenge at the same time no adventure. But if there is too much stress, it is also not good, because it can reduce work performance. Based on the theory, we can see a relationship between stress and performance in the form of an inverted $U$ curve, where this curve shows the relationship between performances (measured with low work performance to high work performance) with stress level (measured from low stress level Up to high stress levels). A reverse U-shaped curve hypothesis has long been accepted as an explanation of the relationship between work stress and performance.Iswanto (2002) reveals: some of the latter studies do not support the hypothesis of an inverted $U$ curve. 
Miner (1988) in Iswanto (2002) found that performance tended to decrease with increasing stress. This is supported by Sullivan et al., 2000 in Iswanto (2002) which states that the study of stress (measured by role ambiguity, role conflict, role overload) and the study of performance, found that work stress has a negative relationship with performance.

\section{The Correlation of Work Stress towards Turnover Intention}

Job stress is associated with reduced performance, and is associated with high turnover intention. According to Rajeb et al., 2013: role stressors, role conflict, role ambiguity, role overload, and role novelty have a positive relationship to turnover intention. According to Jackson (1995) in Viator (2000), stress is related to decreasing performance, also associated with high desire ("new desires") to leave the company (turnover intention). This opinion is also supported by Behrman et al., 1984in Singh (1998) for testing the effect of stress on the work of salespeople, where the results of the test indicate the influence of job stress that comes from the role of individuals in the organization to performance, satisfaction, tension, and organizational commitment. Job stress negatively affects performance, satisfaction, and organizational commitment, and positively affects the intention of moving companies.

\section{The Correlation of Performance with Turnover Intention}

Mc Evoy (1987) in Scotter (2000) states that performance and turnover intention have a negative relationship. This is in accordance with the results of Rajeb et al., 2013 which concluded that performance has a negative relationship to turnover intention. Negative relationships show that employees with good performance have a tendency not to quit their jobs, and vice versa, and keep in mind that turnover intention is considered functional, if employees with poor performance become out of work.

\section{Research Variables}

The variables in this research consist of exogenous variableswhich consist of role ambiguity, role conflict, and role overload variables, and endogenous variables which consist of performance and turnover intention variables. The following conceptual framework is to explain which variables are located as exogenous variables and which variables are located as endogenous variables. The prepositions are based on theoretical studies (theories and concepts) and empirical studies, the hypotheses and how the causal relationships between the research variables (see the research conceptual framework) are found.The research conceptual framework is in the following.

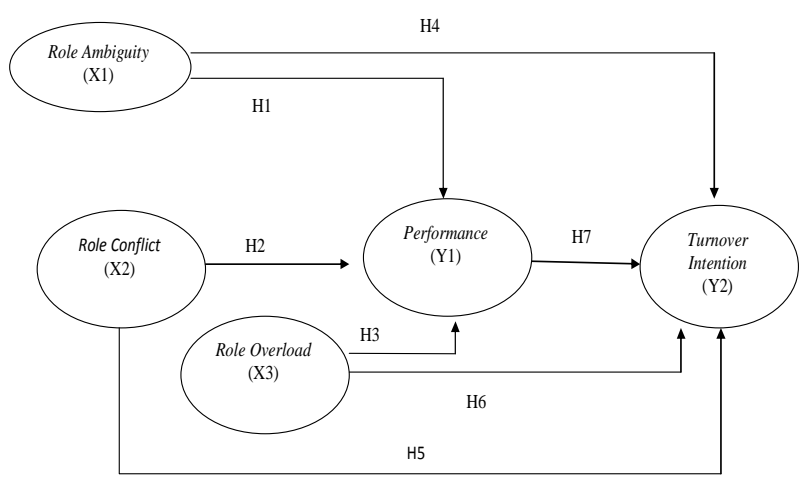

Source: Theories developed by researcher.

\section{Research Hypotheses}

Hypotheses in this research are as follows: 1). Role ambiguity significantly influence the PPEE performance in Surabaya, 2). Role conflict has a significant effect on the PPEE performance in Surabaya, 3). Role overload significantly effect on PPEE performance in Surabaya, 4). Role ambiguity significantly influences PPEE turnover intention in Surabaya, 5). Role conflict significantly influences PPEE turnover intention in Surabaya, 6). Role overload has significant effect on PPEE turnover intention in Surabaya, and 7). Performance significantly influences PPEE turnover intention in Surabaya.

\section{RESEARCH METHODOLOGY}

This research uses quantitative research design. The unit of analysis is PPEE from Securities Company located in Surabaya, with research population of 734 PPEE spread over 44 Securities Company residing in Surabaya, while research sample is done by purposive.

Quantitative data is used in this research because it will be analyzed by statistical analysis. Maholtra (2005) states that in the study, "used" for two reasons: 1). Figures allow statistical analysis to be carried out on the generated data, 2 ). Figures facilitate communication of measurement rules and results. Data source used is primary data and secondary data. The primary data of this research are data obtained directly from PPEE and PPEE superiors from 44 securities firms located in Surabaya, through questionnaires, interviews, and observations (direct observation). Questionnaires are structured for the purpose of obtaining data on the variables studied from the respondents. While secondary data in this research is data obtained from conducting literature study related to the problems studied. The stages in conducting data analysis include quantitative analysis and qualitative analysis. After all data is collected, then data analysis is done by editing, tabulation, and doing data processing that is adjusted with research approach, and in this section data is processed by using the formula/rules that exist, in accordance with research approach/research design used. Statistical data analysis for this research is done by using the Structural Equation Model. 


\section{Definition of Operational Variables}

\section{Role Ambiguity Variable}

Role ambiguity or role blurring is a condition in which PPEE feels unclear or confused with the definition of work received from Securities Companies where PPEE works. The role ambiguity variable is given $\mathrm{X} 1$ notation, with the following indicators:

1. Unclear definition of PPEE assignment description (X1.1).

2. Uncertainty which is the limit of responsibility of PPEE to clients, i.e. investors (X1.2).

3. The disguise which is the limit of authority of PPEE to the investors (X1.3).

4. Lack of information from Securities Companies to PPEE at any time of policy change (X1.4).

Measurement of the value of the role ambiguity variable is based on the sum of scores from the respondent's answer to the PPEE, or which is the PPEE statement compiled on the basis of the Likert Scale of seven points.

\section{Role Conflict Variable}

Role conflict (with notation X2) is a condition in which PPEE is required to be able to differentiate and choose between demands and expectations, with the following indicators:

1. Differences of Securities Company's demand on PPEE (X2.1).

2. Differences of investor demand on PPEE (X2.2).

3. Differences in expectation of PPEE with manager or supervisor (X2.3).

4. Violation of regulation/policy of Securities Company by PPEE in execution of duty (X2.4).

Measurement of the value of the role conflict variable is done on the basis of the sum of scores from the respondent's answer to the PPEE, or that is the PPEE statement compiled based on the Likert Scale of seven points. Measurement of role conflict variable sourced from research Rajeb et al. (2013) and Lailah (2006) are modified.

\section{Role Overload Variable}

Role overload is an overload of PPEE as a result of Securities Company demands that exceed the PPEE's resources. There are two types of overload, namely quantitative workload overload and qualitative overload. The quantitative overload of work is that PPEE gets loaded with a lot of work, so there is not enough time to do the work that is charged to it, while the qualitative overload is if the PPEE feels it does not have the necessary skills to complete the job (in this case it does not have the ability to meet target of equity securities transactions and the number of investors obtained) up to the specifiedtime, or if the
PPEE feels less able to perform the tasks which have been assigned to them. Variable role overload given X3 notation, with indicators as follows:

1. Implementing prospects for potential clients/prospective investors outside the hours of work (X3.1).

2. Paying attention to potential clients after the clienthas a Securities Account (Opening Account) in Securities Company (X3.2).

3. Work through the target system within a certain time limit (X3.3).

4. Increase the target volume of equity transaction at any time (X3.4).

5. Able to sell all capital market products (X3.5).

6. Selling new capital market products without prior public education/training about new products referred to in detail (X3.6).

The measurement of the value of the role overload variable is measured by the sum of the scores of the respondents' answers to the PPEE, or which is the PPEE statement prepared on the basis of a seven-point Likert Scale. Measurement of role overload variables sourced from research Rajeb et al. (2013) and Lailah (2006) are modified.

\section{Performance Variable}

The performance variable here is the performance of PPEE. Performance PPEE is a completed PPEE activity, or the PPEE has successfully completed the activity, task or job assigned or charged to it. Performance (variables Y1) can be measured from the quantity, quality, and efforts mobilized for the completion of its work, with indicators used include:

1. Ability to establish effective relationships with clients/investors, so that loyalty clientremains always awake (Y1.1).

2. Able to provide clear and correct information about capital market products to clients/investors, so as to reduce complaints from clients (Y1.2).

3. Ability to resolve problems with respect to complaintsfrom clients (Y1.3).

4. Ability to increase the number of new clients (Y1.4).

5. Capable of achieving the target volume of equity transactions that have been set (Y1.5).

6. Ability to understand the needs and desires of clients(Y1.6).

7. Ability to help speed up the settlement of equity securities transactions (Y1.7).

The measurement of PPEE performance variables is measured on the basis of the sum of the scores of the respondents' answers/statements (in this case the PPEE superiors assessing the performance of PPEE) arranged on a seven-point Likert Scale. Measurement of performance variables derived from Natakoesoemah (2010) and Lailah (2006) studies which have been modified. 


\section{Turnover Intention Variable}

Turnover intention variable (the desire to leave the company) is a desire of the PPEE to leave the company. Job stress is experienced by employees also does not close the possibility of increased desire to move (turnover intention) on employees, or employees leave the company (Flaherty, 2011). Similarly Rajeb et al. (2013) revealed that role conflict, role ambiguity, and role overload have a positive correlation to turnover intention.

The desire to leave the company refers to its relationship to the organization, and is "not realized" in the course of action that leaves the organization. The turnover intention variable is given Y2 notation, with indicators used as follows:

1. PPEE is thinking to leave the company (thinking to quit), with Y2.1 notation.

2. PPEE intends to seek other work (intention to search), with Y2.2 notation.

3. PPEE intends to leave the company (intention to quit), with Y2.3 notation.

Measurement of turnover intention variable value based on the sum of scores of responses/statements of PPEE respondents compiled based on the Likert Scale of seven points. Measurement of turnover intention variables sourced from research Rageb et al. (2013) and Lailah (2006) which has been modified.

\section{RESULT AND DISCUSSION}

\section{The Influence of Role Ambiguity towards Performance}

It can be concluded from the results of the hypothesis 1 test "there is no significant influence between the variable role ambiguities and performance variable of the PPEE in Surabaya". Statistically it is shown by the standardized coefficient of 0.150 and probability of $0.393>$ of the 0.05 level of significance. The test results of Hypothesis 1 are contradictory to the study of stress and performance that has been done by Sullivan et al. (1992), who concluded that role ambiguity has a negative relationship with performance, as well as contrary to Viator (2000) research results which concluded that role ambiguity has a negative correlation with work performance. Rajeb et al. (2013) also states through the results of his research that role ambiguity has a negative correlation to performance. Other research results conducted by Tee (2009) also contradict the results of Hypothesis 1 testing of this study, namely that role ambiguity negatively correlated with work performance.

Situations in the field based on observations made, for the PPEE there has been a clear description of tasks/job descriptions, in addition to the availability of SOP (Standard Operating Procedures) which is also clear on Securities Companies in general. The code of ethics as PPEE is contained in a Membership Regulation that has been regulated by the Indonesia Stock Exchange, one of which is to manage its PPEE contained in the Securities Companies. The OJK (Financial Services Authority) also regulates the various rules and regulations required for the PPEE, including regulating the code of ethics of PPEE. Membership Regulations, Code of Conduct and other regulations for the PPEE issued by the Stock Exchange and the OJK also set limits on the responsibilities and limitations of the authority of PPEE on investors.

From the observations made on Securities Companies it is also known that information on policy changes is generally made known to PPEE by such Securities Companies, especially Securities Companies that have become public companies, to which they are required to fully disclosure to all parties, as it is regulated by the OJK, whether disclosure of information within the internal environment of Securities Company and disclosure of information to the investor community (external Securities Company).

The existence of the description of duties and responsibilities, clear limits of authority and the SOP on Securities Companies, and with the regulations which have been issued by the Securities Exchanges and the OJK's that must be obeyed by Securities Companies (i.e.the PPEEs), it can be said thatthere is no role ambiguity in PPEE. This is also supported by the average answer of PPEE respondents to the statement contained in the indicators that make up the role ambiguity variable, which perceives the average role ambiguity between 5.28 (lowest) to 5.33 (highest), or an average of 5.30 (which according to Category Scale is perceived to be "rather high", with intervals between 4.48 and 5.34). With the average indicators that make up the "rather high" role ambiguity variables, it can be said that these indicators are what makes the PPEE role ambiguity increasing in Surabaya. The highest score of 5.33 is in the statement "I feel the disguise that is the limit of my authority as PPEE to my client", so "the disguise is the limit of the authority of PPEE to the PPEE client" is the first thing that makes the PPEE role ambiguity increasing. The second highest score of 5.30 is in the statement "I feel the vagueness of the job description definition as PPEE", so the "unclear definition of job description as PPEE" is the second thing that makes the increasing role of ambiguity PPEE.

Although PPEE respondents on average perceive indicators that form role ambiguity with "rather high" perceptions, it means that PPEE does not perceive these indicators with "high" or "very high" perceptions, which does not result in significant influence between roles ambiguity to the performance of PPEE.

\section{The Influence of Role Conflict towards Performance}

From the result of hypothesis 2 testing can be concluded "there is no influence between role conflict variable to performance variable of PPEE in Surabaya", shown by standardized coefficient 0.267 and probability equal to $0.147>$ from significance level 0.05 . Test result Hypothesis 2 does not match with the research which has been done by Sullivan et al. (1992) which states that role conflict has a negative relationship with performance, as well as not in accordance with research that has been done 
by Rajeb et al. (2013), which states that role conflict is negatively correlated with performance. Similarly, research conducted by Tee (2009) concludes that in addition to role ambiguity, role conflict is negatively correlated with performance, thus the results of Hypothesis 2 testing of this study do not match well with the research results of Tee.

Based on field observations, there is generally no difference in Securities Company's demand for PPEE, no difference of client's demand for PPEE, no difference of expectation of PPEE with manager or supervisor, and no violation of regulation / policy regulated by Securities Company, Stock Exchange, and OJK by the PPEE in the execution of their duties. There is generally good agreement and commitment and negotiation between PPEE and Securities Companies, good agreement and commitment between PPEE and their clients, and good agreement and commitment between PPEE and their manager or supervisor. So EEEE generally comply with the regulations / policies issued by Securities Companies, Stock Exchanges or OJKs. The PPEE does not wish to be sanctioned for violations of regulations / policies which have been issued by Securities Companies, Stock Exchanges or OJKs, so that PPEE generally comply with the rules or policies in the performance of their duties. Sanctions received to PPEE are very likely to cause PPEE to be blacklisted and may be excluded from the Securities Company, and this also brings impacts to the Securities Company concerned, in the form of Securities Company image in the eyes of many parties Investors, and publicly-listed companies/companies), which in turn will have an impact on Indonesia's capital market image.

The existence of the regulations and/or policies which have been issued by Securities Companies, Stock Exchanges and OJKs that must be complied with by PPEE in particular as well as by Securities Companies in general, and the existence of sanctions which are punishment for PPEE as well as for Securities Company, and in addition because Good agreement and negotiation between PPEE with investor/prospective investor, between PPEE with manager/supervisor of PPEE, and between PPEE and Securities Company, there is no role conflict in PPEE with other parties.

The absence of role conflict in PPEE in Surabaya that has an influence on PPEE performance is supported by the average answer of PPEE respondents in the statement contained in the indicators forming the role conflict variable, which perceives the average role conflict between 5.02 (The lowest) to 5.35 (highest), or on average by 5.13 (which according to Category Scale is perceived to be "rather high", at intervals of 4.48 to 5.34). With the average indicators that make up the "somewhat high" role conflict variables, it can be said that these indicators are the ones that make the PPEE role conflict increasing in Surabaya. The highest score of 5.35 is in the statement "I oftem feel in conflict with the company policy which is related to the implementation of tasks in the context of achieving the target", so "often contrary to company policies related to the implementation of tasks in the context of achieving the target" is the first thing that makes the increase of role conflict PPEE. The second highest score of 5.14 is in the statement "My work as the PPEE is currently against my wishes or expectations," so "work against my wishes or expectations" is the second thing that makes the PPEE role conflict rise.Although PPEE respondents on average perceive the indicators that form role conflicts with "rather high" perceptions, it means that PPEE does not perceive these indicators with "high" or "very high" perceptions, which does not result in significant influence between roles Conflict to performance of PPEE.

\section{The Influence of Role Overload towards Performance}

From result of hypothesis 3 test which have been done can be concluded that role overload variable significantly influence to performance variable of PPEE in Surabaya, shown by standardized coefficient equal to 0.920 and probability equal 0.000 <significance level 0.05 . The result of Hypothesis 3 testing is in line with the research that has been done by Fried et al. (1998) and Jones et al. (2007) stating that role overload reduces the ability of employees to control their jobs, which in turn can reduce the efficiency and effectiveness of their work, or in other words it can be said that role overload can reduce or decrease performance. Briefly it can be said that role overload brings influence to work performance (performance). Hypothesis 3 test results are also in line with research conducted by Miner (1988) in Iswanto (2002) supported by Sullivan et al. (1992) in Iswanto (2002), that in addition to the influence of role ambiguity and role conflict on performance, there is also an influence between role overload and performance, all of which have negative relationship with performance. Hypothesis 3 test results of this study are also in line with research Behrman et al. (1984) in Singh (1998) conducted on the work of the salespeople, and Behrman et al. Supports Minner's (1988) and Sullivan et al. (1992). Hypothesis 3 test results of this research are also in line with the research of Rajeb et al. (2013) which states that role overload has a negative correlation to performance, and so does the role conflict and role ambiguity have a negative correlation to performance.

If it is observed on the data of the numbers of the available PPEE in Securities Companies in Surabaya, the amount of PPEE is limited. The Securities Company in Surabaya, amounting to 44 companies, has 734 PPEE, so on average every Securities Company has only 17 PPEE. The number of PPEEs in all Securities Companies in Surabaya, which are 734 PPEEs with local investors in Surabaya, amounts to approximately 32,000 investors investing in the capital market (so having Securities Accounts), each average PPEE serves $=32,000$ local investors: $734=43.5$ local financiers Surabaya (44 local investors Surabaya). Whereas if the number of 734 PPEEs serves 57,788 local investors in East Java, then this means every average PPEE serves $=57,788$ local investors: $734=78.7$ local investors in East Java (79 local financiers in East Java). It is apparent here that every PPEE in Surabaya must serve the local capital of Surabaya and serve the local capital of East Java in a number not counted yet, serving foreign investors, while foreign investors in Indonesia dominate the number of investors in Indonesia. On the ground, a PPEE not only 
serves clients to carry out securities trading, but also conducts financial analysis of open companies and market analysis to deliver to clients so that clients can make investment decisions Securities, decisions to purchase securities, and the decision to sell securities, and in addition, PPEE also performs administrative/operational tasks, seeks new clients, maintains or maintains old clients, and even generally As a marketer (marketer). As a marketer, PPEE must be able to introduce the investment products offered by the Securities Company in which they work, as well as introduce the Securities Company. As a market driver, the PPEE are asked to look for new clients in an effort to increase the volume of securities trading transactions, as one way to increase the volume of securities trading transactions is to increase the number of clients, and in the meantime the PPEE also needs to maintain clients Their former clients, with a view to retaining their old clients in order to remain customers in the Securities Company where the PPEEs work, and can still make transactions through the Securities Company they work for. Observing the activities / work performed by PPEE as mentioned above, it can be seen that the workload of PPEE is quite a lot and time consuming. The dominant thing that takes time for PPEE is based on the answers of PPEE respondents on the distributed questionnaires is "to carry out prospects to prospective clients outside of working hours in order for prospective clients to open a Securities Account" and to "maintain a sustainable relationship with clients who already have Securities Account ". By looking at and observing the various activities, as previously mentioned to be done by PPEE, then again it can be concluded that the workload of the PPEE is so great that it can affect their performance. When the load of a large "PPEE" job will decrease PPEE performance, while in the case of a reduced PPEE workload, it will be able to boost PPEE performance.

The occurrence of PPEE role overload in Surabaya which has an influence on PPEE performance, is supported by the average answer of PPEE respondents on the statement contained in the indicators forming the role overload variable, which perceives the average role overload between 4.95 (lowest) Up to 5.47 (highest), or an average of 5.27 (which according to Category Scale is perceived to be "rather high", at intervals of 4.48 to 5.34). With the average indicator that makes up the "somewhat high" role overload variables, it can be said that these indicators are what make the PPEE role overload rise in Surabaya. The highest score of 5.47 is in two statements: "I am conducting prospects for prospective clients outside of working hours" and "My relationship with clients continues even if the client has a Securities Account", thus "executing prospects for prospective clients Outside of working hours "and" continuing client relationships even if the client already has a Securities Account "are the two main things that raise the role of PPEE role overload. The third highest value (amounting to 5.39) is in the statement "I am trying to reach the target which has been set for a limited time, that is, the target of equity trading transaction", so that "the achievement of the target that has been set in a limited time in the form of the achievement of the amount Trading volume of equity securities transactions "is the third thing that makes the increase of PPEE role overload.

\section{The Influence of Role Ambiguity towards Turnover Intention}

From result of hypothesis 4 testing which have been done can be concluded that role ambiguity variable has no significant effect to PPEE turnover intention variable in Surabaya, as indicated by standardized coefficient is -0.060 and probability $0.807>$ from level of significance 0.05 . The results of hypothesis 4 testing are not in line with the results of Viator (2000) research, where Viator concludes from his research that role ambiguity has a positive correlation to turnover intention, and so Flaherty (2011) concludes that work stress is experienced by employees, The only one measured by role ambiguity, does not close the possibility of increased turnover intention employees, as well as Rajeb et al. (2013) reveals that role ambiguity has a positive correlation to turnover intention. Just as explained before, because PPEEs do not experience the vagueness of the role (no role blurring), it makes no impact on the performance of PPEE in Surabaya, Also makes no impact on PPEE turnover intention in Surabaya. The absence of PPEE role ambiguity is also reinforced by the responses of PPEE respondents to indicators that measure the role ambiguity variables that have also been discussed previously.

\section{The Influence of Role Conflict towards Turnover Intention}

From the result of Hypothesis 5 test, it can be concluded that the variable role conflict does not significantly influence the PPEE turnover intention variable in Surabaya, which is shown by the standardized coefficient of 0.351 and the probability of $0.205>$ from the 0.05 significance level. The results of Hypothesis 5 are different from Viator (2000) and Rajeb et al. (2013). Viator concludes that role conflict has a relationship with turnover intention, or Viator concludes conclusively that role conflict is positively correlated with turnover intention, and while Rajeb et al. it can be concluded that the role conflict has a positive correlation to turnover intention. Just as explained before, because the PPEE does not experience role conflict, there is no influence between the variable of conflict conflict with the variable of intention turnover. The absence of role conflict in self PPEE in Surabaya is strengthened by respondents' answers to the PPEE indicators that measure the role conflict variables that have also been discussed previously.

\section{The Influence of Role Overload towards Turnover Intention}

From the test result to Hypothesis 6 it can be concluded that role overload variable significantly influence to PPEE turnover intention variable that exist in Surabaya, shown by standardized coefficient 0.977 and probability equal to 0.012 <from level of significance 0.05 . Test results hypothesis 6 of this study supports research that has been done by Rajeb et al. (2013) stating that role overload is positively correlated with turnover intention. Because the 
PPEE has experienced role overload, there is a significant influence between role overload and turnover intention. This means that when PPEE's overload role occurs in Surabaya, it will be followed by increased turnover intention, and vice versa when the role overload is not experienced by PPEE in Surabaya, there will be a decrease in turnover intention. This is also supported by respondents' responses to PPEE statements on indicators that measure role overload variables, as described previously.

\section{The Influence of the Performance towards Turnover Intention}

From the result of hypothesis 7 test, it can be concluded that the performance variables significantly negatively affect the PPEE intention turnover variable in Surabaya, as indicated by the standardized coefficient of 0.733 and the probability $0.047<0.05$ significance level. There is a significant negative influence between performance variables on PPEE turnover intention variables, this means that if PPEE has a good performance, it has a tendency to not quit its job in Securities Company, and vice versa if PPEE has poor performance, tend to quit its job in Securities Company. Mc Evoy (1987) in Scotter (2000: 82) states that performance and turnover intention have negative relationships, meaning that employees with good performance have a tendency to not quit their jobs, and poorly performing employees, or employees who cannot meet or be under the qualifications (performance standards) that the company has set, has a tendency to quit its job. Thus the results of Hypothesis 7 test are in line with those already delivered by Mc Evoy.

Meanwhile Rajeb et al. (2013) through the results of his research revealed that the performance has a negative correlation to turnover intention, meaning that with good performance of employees, the employee is not willing to get out of his job, or not willing to leave his job, while employees with poor performance, is willing to get out of his job or desire to leave his job. Thus the results of testing Hypothesis 7 of this study are also in line with the results of research that has been done by Rajeb et al. (2013). On the basis of observations on the ground it appears that at the time of PPEE's performance, PPEE still joined the Securities Company, and there is no PPEE intention to leave the company. When the PPEE is not performing, there is a PPEE intention to leave the Securities Company, where the culmination is that PPEE actually leaves the company. Basuki (2014) states that several Securities Companies have reported PPEE out in the same year, among others, that one of the private securities companies headquartered in Jakarta, with its branch offices in Yogyakarta, Surakarta, Surabaya, and Several other cities, has been out by 30 PPEEs. In Bandung, still according to Basuki, out of a number of PPEEs resulted in a private Securities Company being forced to close, and similar things have happened to other Securities Companies, including companies with StateOwned Enterprises (BUMN) status.

It can be seen from the responses of PPEE superiors who evaluated the performance of PPEE, that the average answer of PPEE superiors on the statements contained in the indicators measuring the performance variables perceives the average performance between 4.19 (the smallest value) to 5.23 (value highest), where the average performance for all indicators has been calculated at 4.73 (according to Category Scale perceived "rather high", i.e. at intervals of 4.48 to 5.34). The highest score (5.23) is found in the respondent's answer which states "the ability of PPEE helps speed up the transaction settlement process", while the smallest value (4.19) is found in the respondent's answer stating "the ability to solve the problems related to the complaint / Complaint financiers ". The second smallest value (value 4.44) is found in the respondent's answer which states "the ability to give clear and correct information about the capital market product to the investor, so as to reduce the complaint/complainant of financiers", while the third smallest value (value 4.61) On the respondent's answer stating "the ability of PPEE in establishing an effective relationship with investors, so that loyalty investors always awake". In Securities Company, the ability to solve problems related to complaints/complaints of investors, the ability to provide clear and true information about capital market products to investors, so as to reduce complaints/complaints of investors, and the ability of PPEE in establishing effective relationships with investors, so that the loyalty of investors is always awake is a crucial thing that describes the performance of PPEE, because it will be able to increase the amount of value of trading volume of securities transactions, increase the value of market capitalization of securities, in addition to adding new investors, due to the old investors who have been (which is currently a PPEE client), will provide recommendations for new investors to invest through the respective PPEE (i,e., PPEE is capable of handling or resolving issues pertaining to complaints from financiers, and PPEE capable of providing Clear and true information about investment instruments in the capital market to investors, so as to reduce investor complaints). On the basis of the analysis of respondents' answers relating to the performance of PPEE, it can be seen that the performance of PPEE related to the things mentioned above is still very necessary, so as to further improve the performance of PPEE which can then affect the size of PPEE turnover intention, and ultimately can increase capital market performance.

In addition, the submission of analysis of respondents' answers on the indicators of PPEE measuring turnover intention variables. The average respondent's answer to a statement measuring a turnover intention variable is 4.47 , which according to Category Scale is perceived as "sufficient" (at intervals 3.61-4.47). Although perceived as sufficient, the respondent's answer to one of the indicators that measures the turnover intention variable is perceived to be "rather high", i.e., 4.67 (the rather high-Scale Category interval is 4.48-5.34). The answer of PPEE respondents on one of the indicators that measure the turnover intention variable is on the statement "I as PPEE thinking to leave the company (thinking to quit). So it turns out PPEE respondents in general declared thinking to leave the Securities Company.On the basis of the analysis of respondents' answers on PPEE indicators that measure the performance of PPEE and PPEE turnover intention, it can be 
concluded that the above analysis supports the results of Hypothesis 7 test which states that the performance of PPEE in Surabaya influences PPEE turnover intention in Surabaya, which is also supported by Research Rajeb et al. And Mc Evoy.

\section{CONCLUSIONS}

\section{Conclusions}

The conclusions of this research are: 1). There is no influence between role ambiguity on PPEE performance in Surabaya, 2). There is no influence between role conflict on PPEE performance in Surabaya, 3). There is influence between role overload on performance of PPEE in Surabaya, 4). There is no influence between the role ambiguity of PPEE turnover intention in Surabaya, 5). There is no influence between role conflict on PPEE turnover intention in Surabaya, 6). There is influence between role overload on PPEE turnover intention in Surabaya, and 7). There is influence between performance of PPEE to PPEE turnover intention in Surabaya.

\section{Findings}

Some findings of this research are: 1). The number of domestic investors in the capital market in Indonesia is still very limited, reaching only about 400 thousand people (less than $0.1 \%$ of the number of Indonesian middle class who already have a Securities Account as an active sign of being a financier in the Indonesian capital market 2). Foreign investors dominate equity ownership (stock), so that decisions that are strategic to companies that are incorporated as Limited Liability Companies (PT) are dominated by foreign parties. Until the end of 2013, foreign share ownership reached $62.80 \%$ while up to June 2014 , foreign ownership is still high, reaching as much as $63.42 \%$, and 3 ). There was a sharp decline in trading volume of equity securities, which in 2010 decreased $9.32 \%$, in 2011 decreased $9.57 \%$; And in 2012 decreased by $12.45 \%$, where this decline showed a decrease in PPEE performance in terms of achievement of trading volume of equity securities.

\section{PRACTICAL IMPLICATION}

Suggestions as the practical implication that can be given from this research are as follows: 1). PPEE supported by the Financial Services Authority (OJK), Indonesia Stock Exchange and Capital Market Supporting Institution and Capital Market Professional Institution need to work together to increase the number of domestic investors, 2). Promote market makers to increase the volume of equity trading transactions, 3). PPEE is advised not to perform administrative tasks, so that PPEE does not experience role overload, so that intention turnover can be lowered, 4).Incentive reward system improvement for the PPEE.

\section{REFERENCES}

[1] Babakus, Emin, David W. C., Johnston, Marck, dan Moncrief W. C. 2006.Examining the Role of Organizational Variables in the Salesperson Job Satisfaction Model, Journal of Personal Selling \&Sales Management Volume XVI, No. 3, 33-46.
[2] George, Janifer M., Joner G. R. 2002. Organizational Behaviour. Prentice-Hall, New Jersey.

[3] Iswanto, Yun. 2002. Summary of Citing Internet Sites:Analisis Hubungan antara Stres Kerja, Kepribadian, dan Performance Manajer Bank(online). http://202.159.18.43/JsI/111yun.htm, it was accessed on December 5th, 2011.

[4] Maholtra, Naresh K. 2005. Marketing Research: An Applied Orientation, fourth edition, New Jersey: Upper Saddle River.

[5] Marck P. Leach, James S. B., Thomas Brahear. 2007. The Impact of Supportive Environments on Salesforce Performance, Advance in Marketing Science No. 20, 243-55.

[6] Margiati, Lulus. 1999. Stres Kerja: Latar Belakang Penyebab dan Alternatif Pemecahannya. Jurnal Masyarakat, Kebudayaan dan Politik, Surabaya: Fakultas Kesehatan Masyarakat Universitas Airlangga, 71-80.

[7] Munandar, Ashar S. 2001. Psikologi Industri dan Organisasi, Jakarta: Penerbit Universitas Indonesia.

[8] Rajeb, Mohamed A., Abd-El-Salam, Eman Mohamed, El-Samadicy, Ahmed, Farid, Shaimaa. 2013. Organizational Commitment, Job Satisfaction and Job Performance as a Mediator between Role Stressors and Turnover Intentions, a Study from an Egyptian Cultural Perpectives, Journal of Business \& Management Review, Vol.3, No. 2.

[9] Robbins, Stephen P., Judge, Timothy A. 2008. Organizational Behavior, Edisi 13, New Jersey: Prentice Hall International, Inc.

[10] Samsuri, Moch. 2011. Makalah: Turn Over Perantara Pedagang Efek, PT Reliance Securities TbkSurabaya.

[11] Scotter, James R. V. 2000. Relationship of Task Performance and Contextual Performance with Turnover, Job Satisfaction, and Affective Commitment, Human Resource Management Review Volume 10, No. 1, 79-95.

[12] Siagian. 2010. Manajemen Sumber Daya Manusia. PT Bumi Aksara, Jakarta.

[13] Singh.1998. Striking a Balance in Boundary Spanning Positions: an Investigation of Some Unconventional Influences of Role Stressor and Job Characteristics on Job Outcomes of Salespeople, Journal of Marketing Volume 62 No. 3, 69-86.

[14] Tang dan Chang. 2010. Impact of Role Ambiguity and Role Conflict on Employee Creativity, Journal of Human Resource Management Review.

[15] Tee, Edward. 2009. Analisis Pengaruh Stres Peran terhadap Performance Agen Asuransi (Studi Kasus pada PT ACE Life Assurance. Tesis pada Program Studi Magister Manajemen Universitas Surabaya.

[16] Tohardi, Achmad. 2002. Pemahaman Praktis Manajemen Sumber Daya Manusia, Universitas Tanjung Pinang.

[17] Towner, Lesley. 2010. Managing Employee Stress. The University of Manchester Institute of Science \& Technology (UMIST), Manchester.

[18] Viator, Ralph. 2000. The Association of Formal and Informal Public Accounting Mentoring with Role 
Stress and Related Job Outcomes, Accounting, Organizations and Society 26, 73-93. 